Western University Scholarship@Western

Aboriginal Policy Research Consortium International (APRCi)

2003

\title{
Botany bay: Voyagers, aborigines and history
}

Maria Nugent

Monash University

Follow this and additional works at: https://ir.lib.uwo.ca/aprci

Part of the Cultural History Commons, and the Political History Commons

Citation of this paper:

Nugent, Maria, "Botany bay: Voyagers, aborigines and history" (2003). Aboriginal Policy Research Consortium International (APRCi). 414.

https://ir.lib.uwo.ca/aprci/414 
This article was downloaded by: [University of Western Ontario]

On: 16 December 2012, At: 07:42

Publisher: Routledge

Informa Ltd Registered in England and Wales Registered Number: 1072954 Registered office: Mortimer House, 37-41 Mortimer Street, London W1T 3J H, UK

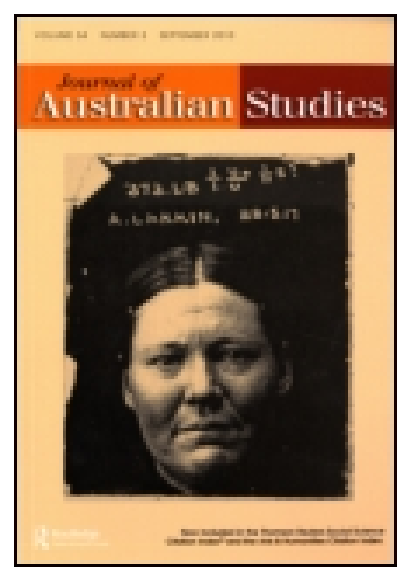

\section{J ournal of Australian Studies}

Publication details, including instructions for authors and subscription information: http:// www.tandfonline.com/loi/ rjau20

\section{Botany bay: Voyagers, aborigines and history}

Maria Nugent ${ }^{\text {a }}$

${ }^{a}$ Lecturer in the School of Historical Studies, Monash University Version of record first published: 18 May 2009.

To cite this article: Maria Nugent (2003): Botany bay: Voyagers, aborigines and history, J ournal of Australian Studies, 27:76, 27-33

To link to this article: http:// dx. doi.org/ 10.1080/14443050309387821

\section{PLEASE SCROLL DOWN FOR ARTICLE}

Full terms and conditions of use: http://www.tandfonline.com/page/terms-and-conditions

This article may be used for research, teaching, and private study purposes. Any substantial or systematic reproduction, redistribution, reselling, loan, sub-licensing, systematic supply, or distribution in any form to anyone is expressly forbidden.

The publisher does not give any warranty express or implied or make any representation that the contents will be complete or accurate or up to date. The accuracy of any instructions, formulae, and drug doses should be independently verified with primary sources. The publisher shall not be liable for any loss, actions, claims, proceedings, demand, or costs or damages whatsoever or howsoever caused arising directly or indirectly in connection with or arising out of the use of this material. 


\section{Botany Bay: Voyagers, Aborigines and History}

\section{Maria Nugent}

Some time in the mid-nineteenth century a headland on the north side of Botany Bay was given the name La Pérouse in honour of the French navigator Comte de Galaup de Lapérouse. ${ }^{1}$ This memorial gesture was part of a long tradition, beginning in 1788 , whereby the headland was made into a site of memory (lieu de memoire $)^{2}$ to the French navigator and his expedition. Before officially acquiring the name La Pérouse, the headland had been popularly known among the British colonists at Sydney Cove as the French Garden, a name that had likewise mapped the place in the colonial imagination through reference to its temporary occupation by the Lapérouse expedition. This association between the site and the expedition, or more particularly its leader, had been enacted in other ways during the first half of the nineteenth century, namely through monuments, pilgrimages and the repeated telling in the metropolitan press of the story of the expedition's voyage and subsequent disappearance after sailing from Botany Bay in March 1788.

The Lapérouse expedition was the last in a series of three significant late eighteenth century visits to Botany Bay. It had been preceded by Captain James Cook's expedition in 1770 , a visit that has retrospectively been regarded as foundational to the making of the Australian nation. That visit lasted about a week, during which time Cook and his crew engaged in various tasks associated with voyages of discovery, such as mapping, botanising and observing the 'natives'. After Cook came the First Fleet under the command of Captain Arthur Phillip. This visit in 1788, as is well known, was the direct result of Captain Cook's earlier sojourn, inasmuch as the intelligence provided by Joseph Banks about Botany Bay was instrumental in its selection as the site for a penal colony. As is also well known, Captain Phillip was unimpressed by what he saw at Botany Bay and wasted little time in locating an alternative site for the new colony, further north at Sydney Cove. It was on his way out of Botany Bay, a few days after first arriving, that Phillip encountered the French expedition sailing in. The arrival of the French expedition was not accidental. Lapérouse had been instructed to make a detour to Botany Bay to observe the new British colony before returning to France. There was, however, little for him to observe given that the First Fleet had preceded him by only a few days. Nevertheless, while the new British colony was being established at Sydney Cove, the Lapérouse expedition remained at Botany Bay for about six weeks, setting up a temporary camp on the north head and making preparations for the last leg of its voyage. ${ }^{3}$ The Lapérouse expedition sailed in March 1788, but was never heard from again, making the north headland of Botany Bay the last place 'whence any account of [Lapérouse] has been received'. ${ }^{4}$ The disappearance of the expedition after leaving Botany Bay explains in large part why the memory of the French expedition has endured there for so long.

The details of these three encounters at Botany Bay have been the subject of considerable historical scholarship, and have come to occupy a prominent place in 
stories of the Australian nation. This is especially so in relation to Captain Cook, although his promotion to the status of forefather was arguably more a twentieth century phenomenon than a nineteenth century one..$^{5}$ Indeed, during the nineteenth century, as some contemporary commentators have observed, the memory of Captain Cook was somewhat overshadowed by that of Lapérouse, who was far more ostensibly monumentalised at Botany Bay. ${ }^{6}$ This gradually changed in the twentieth century. As a new nation conscious of its origins, the memory of Captain Cook was resurrected, and Botany Bay was one place in which that memory was visibly preserved. This was particularly true of the site of Cook's first landing on the southern shore, which had been handed back to the New South Wales government as a public reserve in 1899. In the process, the story of the Lapérouse expedition was grafted onto that of Captain Cook. These two histories, now sharing the same space, were discursively joined through reference to sharing a common goal of imperial scientific curiosity, leading to the discovery of new lands but not themselves directly engaged in colonisation. Representing Lapérouse in the mould of Captain Cook rather than Captain Phillip arguably eclipsed a popular belief that the French expedition may have constituted a threat to British colonisation.?

During the nineteenth century and the first half of the twentieth century, Captain Phillip was not monumentalised at Botany Bay. His memory belonged at Sydney Cove, and it was around Sydney that memorials were erected to him. Nonetheless, the arrival of the First Fleet was regularly referred to in popular and commemorative descriptions of Botany Bay. Yet by 1950 , in a climate in which commemorating 'firsts' continued to be popular in public forms of history making, there were moves to erect a monument to Phillip's landing place at Botany Bay. This was eventually realised in $1956 .^{8}$ Thus, by the mid-twentieth century, the foreshore of Botany Bay was dotted with monuments to all three late eighteenth century visitors, and their names were applied to various features of the landscape.

This site of memory to late eighteenth century voyagers and colonisers was also home to Aboriginal people, possibly before 1770 but certainly from the late 1870 s onwards. ${ }^{9}$ It is almost impossible to know whether those Aboriginal people living on the north head of Botany Bay in the late 1870 s were directly descended from those who had been living there in the time of Cook, Phillip and Lapérouse. In 1835, Mahroot, an Aboriginal man originally from Botany Bay, claimed in evidence to a select committee inquiry that he was the last of his people, suggesting that there was no such link. ${ }^{10}$ There is fragmentary evidence that Aboriginal people were living around Botany Bay in the mid-nineteenth century. For instance, an 1864 painting of the north headland of Botany Bay showing the Lapérouse monument (which had been erected in 1828) and the grave of a priest on board the expedition who had died while at Botany Bay depicts a group of Aboriginal people and their dogs in the foreground. " Such an image cannot be interpreted necessarily as incontrovertible evidence that Aboriginal people were living near the monument. The Aboriginal people depicted may have been figurative rather than actual representations of presence, perhaps to make a statement about the inevitable passing of Aboriginal people in the wake of the imperialism that Lapérouse embodied. But, on the other hand, the painting could be used to suggest an Aboriginal presence in this place at that time. Other evidence includes a sketch drawn in 1819 of an Aboriginal man named Timbere. ${ }^{12}$ Again, 
this sketch does not necessarily link its subject to Botany Bay at the time it was drawn. It has since, however, been used as the basis for claims about unbroken connection to this general area by one well known Aboriginal family living at La Pérouse - the Timberys. Certainly, the sketch does seem to provide some evidence about enduring connection, although specific links between the man in the sketch and twentieth-century Timberys have not been firmly established.

While reconstructing the presence of Aboriginal people at Botany Bay prior to the mid-nineteenth century is a difficult task for the historian, particularly given the nature of the records, it is certain that there was a group of about five Aboriginal families living permanently on the northern headland by the late $1870 \mathrm{~s}^{13}$ By 1881 , this camp had come to the attention of the newly appointed Protector of Aborigines, George Thornton. ${ }^{14} \mathrm{He}$ and some colleagues had become increasingly concerned about the growing presence of Aboriginal people in Sydney, and had undertaken measures to remove them from the metropolis. During this 'clean up' campaign, the camp at La Pérouse on the periphery of Sydney came under scrutiny, although unlike other camps around the city it was allowed to remain, and subsequently became a place to which Aboriginal people were relocated. From this time onwards the settlement grew, becoming a more permanent and visible feature of the northern headland, sharing that space with the memory of the Lapérouse expedition. Both associations contributed to the popular meanings of this headland in the metropolitan imagination. It was a 'popular' site in both senses of the word. For instance, during the nineteenth century the north headland of Botany Bay was known in the metropolitan imagination through reference to the ill-fated French expedition and was second only to the south head lighthouse in popularity for picnic parties and outings. ${ }^{15}$ This explains the large archive of visual images of the Lapérouse monument, many sketched or painted by visitors. ${ }^{16}$ In the twentieth century, La Pérouse was popularly known as the 'home of Aborigines' among Sydneysiders. It was hugely popular with tourists and day trippers alike; local Aboriginal people performed there on weekends attracting tram-loads of visitors. By then, it had also become the 'gateway to the birthplace of the nation', providing the most direct route, via ferry, to Captain Cook's landing place on the opposite side of the bay.

This dual occupation of the space by Aboriginal people and the memory of late eighteenth century visitors, since honoured as being responsible for setting in train the course of events that led inevitably to the founding of the nation, makes La Pérouse a particularly evocative site through which to explore the politics of history making. This is especially true for Aboriginal people's history making in response to the colonial historical narratives associated with Botany Bay. It is particularly rich for such an enquiry primarily because it is a site where history is ever-present, and where history making has been central to the processes of place making. In other words, it is a place where Aboriginal people cannot avoid the effects of national histories, and where their own histories and those of the nation seem to be constantly in conversation with each other, even when that conversation is punctuated by long silences.

Since the 1970s, Aboriginal history has emerged as a significant field of scholarship that has fundamentally challenged dominant understandings of the Australian past. ${ }^{17}$ It has examined the experiences of Aboriginal people in the colonial past, sometimes emphasising the destructive impact of the new colonial 
order on Aboriginal people, and at other times emphasising Aboriginal people's courage and creativity in responding to that new order. However, regardless of the emphasis given, this scholarship has been concerned with interpreting the impact of historical processes upon Indigenous peoples. In other words, Indigenous people have been the subject of this historical scholarship. Likewise, scholarship has emphasised the impact of history upon Aboriginal peoples.

However, in this body of work very little attention has been given to Aboriginal people actively engaged in producing histories themselves, at least prior to the 1970s. It has been well documented that from the 1970s onwards, in conjunction with the attention given by non-Aboriginal historians to the 'Aboriginal past', Aboriginal people themselves became actively engaged in narrating their own histories. Examples include writing autobiographies, compiling community histories, recording and publishing oral histories, and modes of story telling like song and drama. Less attention has been paid, however, to the ways Aboriginal people have responded to the historical circumstances in which they have found themselves; for example, how Aboriginal peoples make sense of the past, challenging dominant representations of national, or even local, interpretations. It is arguable that the struggle for Aboriginal rights, particularly in south-eastern Australia, implicitly involved an engagement with national historical narratives or discourses - that denied Aboriginal people any part of the national story. This can be seen in the staging of the Day of Mourning on Australia Day in 1938, an event that powerfully and poignantly highlighted the relationship between national story telling and the denial of citizenship rights for Aborigines. ${ }^{18}$ It has been observed that history is both a discourse of the colonisers and a colonising discourse. ${ }^{19}$ Challenging historical narratives, then, has long been central to Aboriginal people's struggles to alter the colonial structures that impinge upon and, indeed, dominate their lives.

Of the scholarship that has considered Aboriginal people's remembrances of the colonial past, Deborah Bird Rose's interpretation of the Captain Cook myths from northern parts of Australia provides the most productive analysis. Rose theorises the integral relationship between past, present and future and seeks to understand Aboriginal people's engagement with 'alien interpretations' through reference to their own structures of meaning. ${ }^{20}$ Likewise, the essays presented in Bain Attwood and Fiona Magowan's recent collection Telling Stories, which deals with Indigenous forms of story telling or history making, expose Indigenous people's accounts of the colonial past to new modes of interpretation, including those emerging from comparative settler societies and complementary disciplines such as literary studies. ${ }^{21}$ This attention to what we might broadly call Indigenous history making has been made possible through postcolonial approaches to history, particularly through their emphasis on interpreting the ways in which the colonised make sense of their experiences of colonisation. ${ }^{22}$

\section{Narratives of Continuity and Survival}

In 1906, E W O'Sullivan, one time NSW minister for lands, devoted his occasional column in the Daily Telegraph to La Pérouse, a place that he described as being where three histories meet. ${ }^{23}$ The three histories that $O^{\prime}$ Sullivan referred to are somewhat difficult to pinpoint. While he does indeed refer to Cook, Phillip 
and Lapérouse, O'Sullivan seems to combine Cook and Phillip into one history. Lapérouse and the death of a priest who had been aboard the French expedition but had died at Botany Bay are referred to separately. Nonetheless, his meaning was clear. La Pérouse was a place where histories met and was also, he stressed, a place that provided the perfect vantage point from which to view those histories. $O$ 'Sullivan's article is interesting for another reason: he excludes from his vision of history the presence of Aboriginal people at the site. He characterises them, as was common in his day, as a people outside history. More than that, he drew a distinct line between living Aborigines at La Pérouse in the early twentieth century and material evidence about a precolonial Indigenous presence in that same landscape.

Yet there is plenty of evidence to suggest that Aboriginal people living around Botany Bay, particularly at La Pérouse, during the twentieth century were themselves claiming a direct connection to the original inhabitants of that place. For example, by the turn of the century, it was common in local tourist literature to make reference to a claim made by the Timberys (mentioned earlier) that their ancestors had witnessed the arrival of Captain Cook in Botany Bay in 1770.24 Similar claims emerged in sporadic public statements during the first half of the twentieth century. For instance, in 1934, a newspaper article about William Rowley, an eighty-four year old Aboriginal man who had been born at Botany Bay and was still living in that area, mentioned that his mother's mother had witnessed the arrival of the Endeavour in Botany Bay in 1770 when she was a small girl. ${ }^{25}$ King Burraga, an Aboriginal man politically active in the 1930s and living at that time in the Salt Pan Creek camp on the south side of Botany Bay, told the anthropologist A P Elkin that: 'I myself [am] a full Blood Aboriginal of Australia, and 3rd direct descendent of the challenger of Captain Cook, when he landed in Botany Bay, in $1770{ }^{\prime}{ }^{26}$ However, oral testimony indicates that it was common practice among local Aboriginal tourist traders, who sold boomerangs to metropolitan day-trippers near the tram terminus at La Pérouse on the weekends, to make such claims in their sales pitch. ${ }^{27}$ Claims of direct descent from eyewitnesses of Captain Cook's landing no doubt added elements of authenticity to their wares, particularly as this authenticity was sometimes questioned. ${ }^{28}$

But what are we to make of these claims? Are they strategically mobilised stories told by Aboriginal people for explicitly political purposes, such as in the course of making claims to land? Is it possible to determine their validity? Should such claims, in a post-Mabo context, be matters for the investigation of lawyers, not historians? Will the Aboriginal people making these claims be subject to humiliating accusations that they are unfounded?

One approach to solving these dilemmas is proposed by Rose. She suggests that the Captain Cook stories which she recorded in north Australia should be read for their intent and effect rather than their factual content. ${ }^{29}$ This approach is less troublesome in situations where it is obvious that what is said about Captain Cook cannot be taken as evidence. Indigenous narrators often place Captain Cook at sites he did not visit, performing deeds that he did not perform. However, in the stories I am concerned with, claims about Captain Cook's visits have been authentified; in these cases, stories told by Indigenous narrators concur with historical fact. This makes the stakes of historical interpretation a little higher, 
because much more rests (especially in the Native Title era) on the validity or otherwise of such a claim. Nonetheless, the question of intent and effect remains significant and worth considering despite the problem of the burden of proof. Furthermore, pursuing an analysis of the symbolic power of the claim does not (or should not) diminish the possibility that it is also one that is historically accurate.

The intent of the Botany Bay Captain Cook stories (in which he is sometimes referred to as 'Jimmy Cook') ${ }^{30}$ seems to be concerned with narrating continuous occupation of place in order to make claim to that place. So, while the Captain Cook myths recorded by Rose and others trouble over the dissonances between Captain Cook's law and Aboriginal law, the claim made at Botany Bay insists upon continuity. Discontinuities, which came in the wake of Cook, are disregarded. However, discontinuities of violence, disease and immoral law characterise the Captain Cook stories from the northern parts of Australia, arguably where there has been greater cultural continuity than at Botany Bay. This apparent paradox can be explained, in part, in terms of the imperative to narrate survival in a landscape that is fundamentally associated with histories of destruction and dispossession. This emphasis upon continuity is particularly symbolically powerful at Botany Bay, where the survival of the original inhabitants remains open to question. The claim, then, functions as a testament to survival in the absence of incontrovertible evidence about survival, if such survival relies on proving unbroken attachment to place and traditions.

More than this, the claim can be read as insisting upon the survival of Aboriginal people not just in a local sense, but more generally. It is a parallel genealogy to that of the imagined community of the nation in that the 'native' eyewitnesses become a type of original ancestor in the same way that Captain Cook functions as a type of national forefather. This story, then, goes further than simply asserting rights to land. It also functions as a reminder that Aboriginal people are always part of the national story, even if their part in it has been denied.

In this respect, it is a claim that is simultaneously local and national in its intents and effects. It is this doubled or dialectical quality that makes the claim of descent so compelling. In other words, the claim of descent from eyewitnesses to Captain Cook's landing uses national history for local Indigenous purposes on the one hand, and on the other, this local Indigenous story has been used for national purposes in the campaign for Aboriginal rights during the 1970s and 1980s.

To understand the process by which this claim of descent from the original inhabitants of Botany Bay became a local story that was mobilised for national purposes $^{31}$ requires interrogating the role of Botany Bay as an historical site within the emerging national Aboriginal political movement from the 1960s onwards. Australians celebrated the Year of Cook in 1970, which included a reenactment of Cook's landing at Botany Bay in front of the British Royal Family. The Federal Council for the Advancement of Aboriginal and Torres Strait Islanders and the National Tribal Council used the occasion to stage a protest against the way in which the national celebrations denied the effects of the history that Cook embodied on Aboriginal people, and to reiterate their calls for national land rights. ${ }^{32}$ In newspaper representations of the mourning ceremony held on the northern side of Botany Bay near the La Pérouse Aboriginal settlement, reference is made to local Aboriginal people claiming unbroken descent from the original 
inhabitants of the place named Botany Bay by Captain Cook. So, on the one hand, La Pérouse was a symbolic site for such a protest because it was represented as witnessing Aboriginal continuity despite the discontinuity wrought by colonisation. On the other hand, it was an exemplar for the terrible consequences of that colonisation. Thus, it had a dialectical meaning - as a site of survival and of deprivation - which later became more pronounced in national Aboriginal protests against national history making held at the site.

In 1988, another bicentenary was staged, and Botany Bay was once again a site for re-enacting original moments and for highlighting the consequences of that foundational history for Aboriginal people. When the Tall Ships sailed into Botany Bay on 18 January 1988 in an unofficial re-enactment, they were met by a large gathering of Aboriginal protestors and their supporters on the spot where a much smaller group of protesters had gathered in April 1970. ${ }^{33}$ And just as the 1970 protest had emphasised the dark side of Australian history, so too did this demonstration, with many protestors wearing t-shirts with the slogan 'White Australia has a Black History'. But perhaps much had changed too. Later on that month, Botany Bay was used for a different type of Aboriginal protest when Aboriginal people from all over Australia gathered for a night of dancing and singing to celebrate survival and to reclaim the land. It was, as historians who attended noted, a night that suggested a new beginning. ${ }^{34}$ It is arguable whether such a new beginning was ever realised, although the Mabo decision of 1992 has been characterised as such a turning point. Yet, it is certainly the case that the rhetoric of survival and celebration had eclipsed that of mourning. In 1992, this little piece of Botany Bay became the site for a celebration of Aboriginal survival with the staging of the Survival Day concert on Australia Day, an event that was held at La Pérouse over the next few years before relocating to Bondi. By this time, the rhetoric of survival was much stronger, and continued to be strengthened spatially by the depiction of La Pérouse as a place of continual Aboriginal occupation despite, or because of it being the very place where the temporal break between pre- and post-invasion had been enacted.

Botany Bay has been a place for historical encounters in the sense that late eighteenth century visits to the site have been inscribed as historical, especially in terms of the story of the nation. But it has also been a site of historical encounters in that it has been a place, throughout the twentieth century at least, where histories encounter one another. Local Aboriginal histories engaged (and continue to engage) with national histories, particularly around the figure of Captain Cook. Later, those local Aboriginal histories were used in an emerging national Aboriginal struggle for rights. This local and national Aboriginal history making at Botany Bay demonstrates an acute appreciation of the power of historical narratives in twentieth century settled Australia for under-writing claims to place and for structuring relationships between coloniser and colonised. More importantly, it demonstrates an acute awareness of the ways in which the stories we tell ourselves about the past have serious consequences both for how we understand the present and for how we can imagine alternative futures. 